\title{
MITRAL STENOSIS WITH VERY HIGH PULMONARY VASCULAR RESISTANCE AND ATYPICAL FEATURES
}

BY

\author{
J. MACKINNON, E. G. WADE, AND C. F. H. VICKERS \\ From the University Department of Cardiology, Manchester Royal Infirmary
}

A rise in pulmonary arterial pressure is almost invariable in severe mitral stenosis. In many patients it is slight or moderate but in a small proportion the pulmonary circulation reacts with extreme elevation of pulmonary vascular resistance and pulmonary arterial pressure. Some of these patients show the usual features of mitral stenosis but others present a difficult diagnostic problem, for many of the classical signs and symptoms of mitral stenosis may be absent or modified owing to the hindrance to blood flow proximal to the pulmonary capillary bed. From our experience we believe that between five and ten per cent of patients found to require mitral valvotomy show these atypical features and this agrees with the incidence $(7 \cdot 6 \%)$ found by Wood (1954).

The purpose of this paper is to describe the clinical and other features of six such patients and to discuss the results of surgery in five of them.

Methods. The six patients all attended the Department of Cardiology, Manchester Royal Infirmary. They were graded functionally, using the New York Heart Association's classification (1939). The history was elicited in detail and examination made jointly by the authors. Each patient was submitted to routine fluoroscopy and films were taken in the postero-anterior and right and left anterior oblique positions. The films were analysed by the method of Wade et al. (1952). Cardiographic examination consisted of standard leads, augmented unipolar limb leads, and præcordial leads V3R to V6 using Wilson's central terminal.

Five patients were subjected to cardiac catheterization and this was carried out in the usual way. Pressures were recorded with a capacitance manometer or saline monometer (Case 1) with reference to a point $5 \mathrm{~cm}$. below the sternal notch. Blood gases were analysed by the Van SlykeNeil manometric method and expired air in the Haldane apparatus. Cardiac output was estimated by the direct Fick procedure. One patient, following basal estimations, performed graded work on a bicycle ergometer, cardiac output, pressures, and resistances being estimated during the fourth to sixth minute of work; this was considered long enough for a steady state to be obtained (Eliasch et al., 1952; Donald et al., 1954). Cardiac catheterization was repeated in three patients, a variable interval after mitral valvotomy.

Vascular resistances were calculated from the following formulæ and expressed in units as dynes sec. $/ \mathrm{cm}^{-5}$.

Total pulmonary resistance (T.P.R.) $=\left(\mathrm{PA}_{\mathrm{m}}-5\right) \times 1332 /$ C.O. in $\mathrm{ml} . / \mathrm{sec}$.

Pulmonary vascular resistance $($ P.V.R. $)=\left(\mathrm{PA}_{{ }_{\mathrm{m}}}-\mathrm{PCV} \cdot \mathrm{m}\right) \times 1332 / \mathrm{C} . \mathrm{O}$. in $\mathrm{ml} . / \mathrm{sec}$.

Peripheral resistance $\quad=$ BA. $\times 1332 /$ C.O. in $\mathrm{ml} . / \mathrm{sec}$.

Where $\mathrm{PA}_{\cdot \mathrm{m}}=$ mean pulmonary artery pressure in $\mathrm{mm}$. $\mathrm{Hg}$.

$\mathrm{PCV}_{\mathrm{m}_{\mathrm{m}}}=$ mean pressure with catheter tip wedged in peripheral lung field.

$\mathrm{BA} \cdot \mathrm{m}=$ mean brachial artery pressure in $\mathrm{mm}$. $\mathrm{Hg}$.

\section{Clinical Characteristics}

Symptoms. All patients were functionally in Grade IV. A striking feature was the rapidity of progress from slight to almost complete incapacity. Thus, the time from onset of symptoms 2G 449 
to total incapacity was seven years or less in all and under three years in three patients. In all, the limiting symptom was progressive breathlessness on exertion but by the time they were seen in hospital their chief complaint was of exhaustion and a feeling of inability to make any physical effort. Several patients complained: "My legs feel like lumps of lead." Cold extremities and a feeling of permanent fatigue were noted by three patients. Two experienced syncopal attacks on exertion. Four were orthopnœic, three had recurrent hæmoptysis, but only one had attacks of paroxysmal dyspnœa. All suffered attacks of congestive heart failure before admission to hospital and three were extremely resistant to the usual forms of treatment. Failure occurred in each patient when they were still in sinus rhythm and only one (Case 6) had any obvious precipitating factor (pneumonia).

Signs. The facial appearance of five of these patients was striking, with a deep cyanotic malar flush. The extremities were cold and arterial blood pressure tended to be low with a small pulse pressure. The most prominent physical signs-present in all cases-were those of pulmonary arterial hypertension and right ventricular hypertrophy, namely $a$ waves in the jugular venous pulse (Fig. 1), a systolic lift over the right ventricular outflow tract, a right ventricular heave, and a loud split second pulmonary heart sound. All patients had sinus rhythm on admission to hospital but one developed auricular fibrillation before mitral valvotomy (Case 3) and one (Case 5) developed paroxysmal auricular fibrillation during the last week of his life.

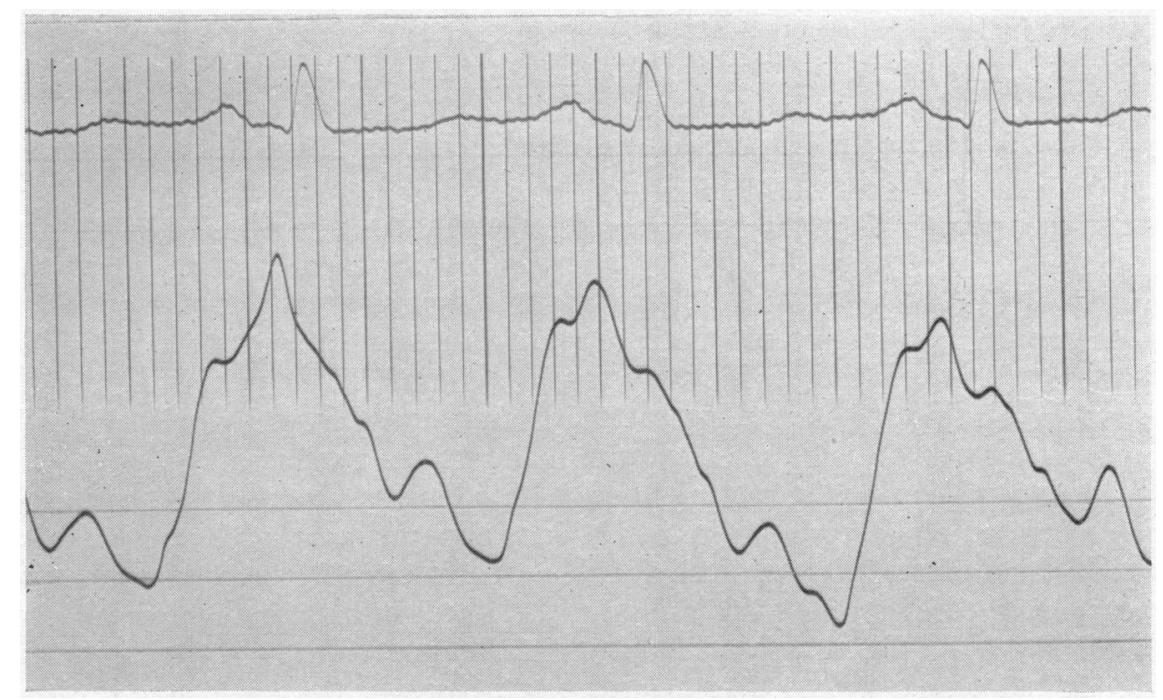

'FIG. 1.-Synchronous recordings of lead II of the electrocardiogram and the jugular venous pulse in Case 6 , showing prominent atrial waves.

The mitral first heart sound was of normal intensity in three patients and increased in three. Calcium was visible on fluoroscopy in the mitral valve in the three patients with a normal first heart sound. The opening snap was not heard in five patients and was doubtful in the other.

Murmurs were notable only for their softness or absence. A soft mid-diastolic murmur was audible in the mitral area in three patients with presystolic accentuation in one: in the other three no diastolic murmur was heard (see Table I). A systolic murmur was present in three patients, at the apex in one and in the left parasternal area in two. A soft diminuendo diastolic murmur was audible down the left sternal border in three and was thought to be due to pulmonary incompetence.

All patients had evidence of pulmonary congestion as judged by the presence of moist râles at the lung bases and two suffered pulmonary infarction, one on several occasions (Case 5). 
TABLE I

Physical Signs

\begin{tabular}{c|c|c|c}
\hline $\begin{array}{c}\text { Case } \\
\text { No. }\end{array}$ & $\begin{array}{c}\text { Mitral } \\
\text { first heart } \\
\text { sound }\end{array}$ & $\begin{array}{c}\text { Mitral } \\
\text { diastolic } \\
\text { murmur }\end{array}$ & $\begin{array}{c}\text { Mitral } \\
\text { presystolic } \\
\text { murmur }\end{array}$ \\
\hline 1 & N & - & - \\
2 & A & + & - \\
3 & N & - & - \\
4 & A & + & - \\
5 & N & - & + \\
6 & A & + & + \\
\hline
\end{tabular}

$\mathbf{N}=$ Normal. $\mathrm{A}=$ Accentuated.

All patients had a right ventricular heave, prominent atrial waves in the jugular venous pulse, and sinus rhythm.

Details of three patients help to illustrate the history and diagnostic difficulties that these patients may present.

Case 3. A woman, aged 31, had chorea at the age of 13 and a heart murmur was discovered when she was 28 , during an uneventful pregnancy. She was first seen complaining of fairly sudden onset of breathlessness on exertion two years before with rapid deterioration since. Twelve months before she had had to stop work on account of exhaustion and was unable to climb a flight of stairs. At this time she had two syncopal attacks on exertion, when she collapsed unconscious for several minutes while walking slightly faster than usual. Her legs always felt very heavy and she complained of cold extremities. Ankle swelling first occurred about nine months before, and two weeks before she was seen she developed pleural pain and hæmoptysis which was thought to be due to pulmonary infarction. She was orthopnœic but had no paroxysmal dyspnoea. When first seen, she was found to have considerable congestive heart failure.

Case 1. A man, aged 29, had served in the armed forces for 4 years during the war. In March, 1950, he first noted breathlessness on exertion and hæmoptysis following an influenzal illness. By September, his incapacity was severe and he complained of permanent fatigue, weariness, and complete exhaustion on any physical exertion. His condition thereafter remained static until January, 1953, when he had two syncopal attacks on exertion lasting about two minutes, and a month later further hæmoptysis and for the first time some ankle swelling. In April he began having repeated small hæmoptyses, became orthopnœic, and had several attacks of paroxysmal cardiac dyspnœa necessitating admission to hospital elsewhere. He was admitted to this hospital in July, 1953. He was a well built man, orthopnœic and breathless on slight exertion. The heart rhythm was normal. Prominent atrial waves were visible in the jugular venous pulse and there was a parasternal heave suggesting right ventricular hypertrophy. The mitral first heart sound was of normal intensity but the pulmonary second sound was loud and split. A loud systolic murmur was audible at the lower end of the sternum but no mitral diastolic or presystolic murmur was present. There was no opening snap. Blood pressure was $110 / 90 \mathrm{~mm}$. Hg. A few crepitations were present at the lung bases and the liver was palpable two finger breadth's below the right costal margin. There was no peripheral œdema. A clinical diagnosis of pulmonary hypertension of unknown ætiology was made and the presence of mitral stenosis was not established until the radiological and catheterization findings were known.

Case 5. A man, aged 29, gave a history of rheumatic fever when he was eight years old but had little incapacity until two years before his first attendance. At this time he became progressively more breathless on exertion and felt completely exhausted. Three months before he was seen he developed congestive heart failure and had recurrent hæmoptyses necessitating admission to another hospital. He was admitted to this hospital with a recurrence of gross congestive heart failure. At this time there was sinus rhythm, prominent atrial waves in the jugular venous pulse, and a right ventricular heave. The mitral first heart sound was of normal intensity and there was no opening snap. The pulmonary second heart sound was loud and split. There was a soft apical systolic murmur but no diastolic or presystolic murmur. There were râles at the lung bases and signs of pulmonary infarction at the right base.

A diagnosis of pulmonary hypertension, probably secondary to mitral stenosis, was made. Unfortunately his heart failure showed no response to rigid salt restriction, digitalis, mercurial diuretics, and a kation exchange resin, and he never became fit enough to catheterize. He developed multiple 
areas of pulmonary infarction, and paroxysms of auricular fibrillation and died five weeks after admission. Autopsy examination revealed a heavily calcified, tightly stenosed mitral valve with right ventricular hypertrophy and pulmonary arterial atheroma.

Electrocardiography. The cardiogram invariably showed the pattern of right ventricular hypertrophy and clockwise rotation of the heart, with high-voltage $R$ waves and inverted $T$ waves extending from V3R to V3 or V4. A typical electrocardiogram is shown in Fig. 3A.

Radiology. The right ventricle was considerably enlarged in all patients. The left ventricle was slightly enlarged in only one. The left atrium was moderately enlarged in two and only slightly enlarged in the remainder.

Extreme prominence of the main branches of the pulmonary artery was present in all patients whereas vascular markings in the peripheral lung fields were "great" in only one, "moderate" in three, and "slight" in two. Horizontal lines due to interlobular œdema (Kerley, 1951) were present in three patients, doubtful in two, and absent in the other. Calcium was visible on fluoroscopy in the region of the mitral valve in three patients.

Fig. 2 shows the chest radiograph of Case 6 with extremely prominent pulmonary conus and main branches of the pulmonary artery, but little or no peripheral pulmonary congestion and no lines due to interlobular œdema in spite of severe mitral stenosis.

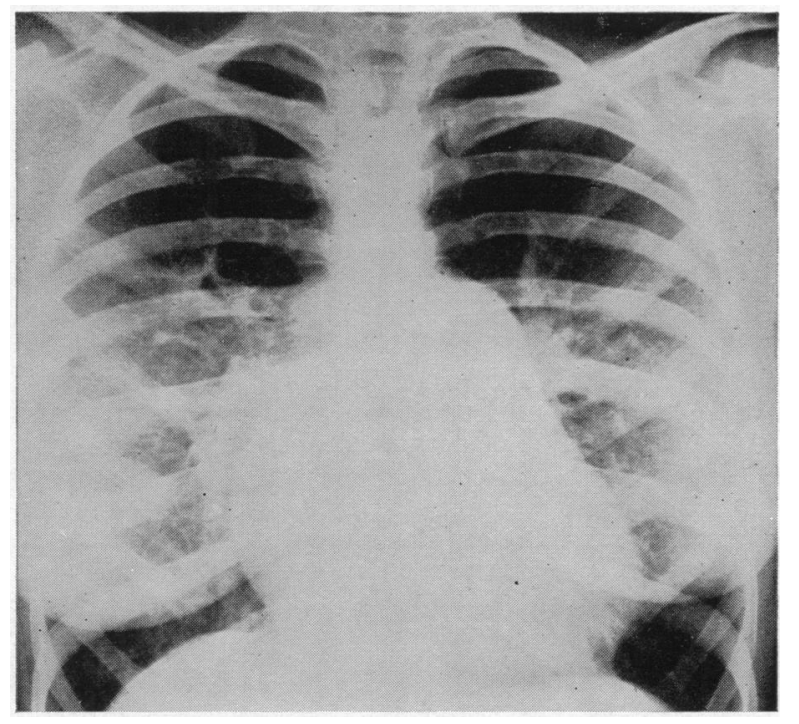

FIG. 2.-Chest radiograph of Case 6, showing prominent pulmonary conus and main branches of the pulmonary artery, but only slight peripheral pulmonary congestion in spite of severe mitral stenosis.

\section{CARDiac CATHETERIzATION}

The results of cardiac catheterization are summarized in Table II. Severe pulmonary hypertension was present in all five patients-the mean pulmonary artery pressure being over $70 \mathrm{~mm}$. $\mathrm{Hg}$ on each occasion. The remarkably high pressure of $177 / 90 \mathrm{~mm}$. (mean $123 \mathrm{~mm}$. Hg) was recorded in Case 6.

P.C.V. pressure was obtained in three patients and was found to be raised, moderately in two and severely in one. This last patient was the only one in the group who had paroxysmal cardiac dyspnœa. The oxygen saturation of mixed venous blood was low (60\% or below) and arteriovenous oxygen difference high in four patients in whom it was measured. Cardiac output was low $(2 \cdot 6,4 \cdot 0$, and $3 \cdot 2$ litres/min.) and total pulmonary resistance was greatly increased $(2580,1310$, and 
TABLE II

Cardiac Catheterization Results

\begin{tabular}{|c|c|c|c|c|c|c|c|c|c|c|c|}
\hline \multirow{2}{*}{$\begin{array}{l}\text { Case } \\
\text { No. }\end{array}$} & \multicolumn{3}{|c|}{ P. A. pressure } & \multirow{2}{*}{$\begin{array}{c}\text { Mean } \\
\text { P.C.V. } \\
\text { pressure } \\
(\mathrm{mm} . \mathrm{Hg})\end{array}$} & \multicolumn{2}{|c|}{$\begin{array}{l}\text { Per cent } \mathrm{O}_{2} \\
\text { saturation }\end{array}$} & \multirow{2}{*}{$\begin{array}{c}\text { A-V } \mathrm{O}_{2} \\
\text { Difference } \\
\text { (vols. \%) }\end{array}$} & \multirow{2}{*}{$\begin{array}{l}\text { Cardiac } \\
\text { output } \\
\text { (1./min.) }\end{array}$} & \multirow{2}{*}{$\underset{\text { index }}{\text { Cardiac }}$} & \multirow{2}{*}{$\begin{array}{c}\text { Total } \\
\text { pulmonary } \\
\text { resistance } \\
\text { (dynes/sec./cm.-5) }\end{array}$} & \multirow{2}{*}{$\begin{array}{c}\text { Pulmonary } \\
\text { vassular } \\
\text { resistance } \\
\text { (dynes/sec./cm.-5) }\end{array}$} \\
\hline & Systoli & Diasto & Mean & & P.A. & B.A. & & & & & \\
\hline $\begin{array}{l}1 \\
2 \\
3\end{array}$ & $\begin{array}{r}126 \\
99\end{array}$ & $\begin{array}{l}64 \\
57\end{array}$ & $\begin{array}{l}74 \\
89 \\
77\end{array}$ & $\begin{array}{l}35 \\
24\end{array}$ & & & $\begin{array}{r}10 \cdot 4 \\
7 \cdot 2\end{array}$ & $2 \cdot 6$ & $1 \cdot 7$ & 2580 & 2000 \\
\hline $\begin{array}{l}4 \\
6\end{array}$ & $\begin{array}{l}125 \\
177\end{array}$ & $\begin{array}{l}44 \\
90\end{array}$ & $\begin{array}{r}72 \\
123\end{array}$ & 25 & & $\begin{array}{l}90 \\
95\end{array}$ & $\begin{array}{l}6 \cdot 1 \\
8 \cdot 0\end{array}$ & $\begin{array}{l}4 \cdot 0 \\
3 \cdot 2\end{array}$ & $\begin{array}{l}2 \cdot 8 \\
2 \cdot 1\end{array}$ & $\begin{array}{l}1310 \\
2930\end{array}$ & 910 \\
\hline
\end{tabular}

P.A. $=$ Pulmonary artery. P.C.V. $=$ Pulmonary capillary venous. B.A. $=$ Brachial artery

2930 units) in three patients in whom these measurements were made; and in view of the low oxygen saturation of mixed venous blood and severe pulmonary hypertension in Case 1 pulmonary resistance must also have been very high in this patient. Arterial oxygen saturation was slightly reduced in two and was normal in two patients.

The effect of exercise was observed before valvotomy in one patient (Case 4; Table III). During exercise a striking increase in total pulmonary resistance occurred (1310 to 2450 units) and was associated with a fall in cardiac output from 4.0 to 3.0 litres/min. and a rise in mean pulmonary artery pressure from 72 to $94 \mathrm{~mm}$. $\mathrm{Hg}$.

TABLE III

Effect of Exercise on Vascular Dynamics in Case No. 4

\begin{tabular}{|c|c|c|c|c|c|c|c|c|c|c|}
\hline & & & \multirow{2}{*}{$\begin{array}{c}\text { Mean } \\
\text { P.A. } \\
\text { pressure } \\
(\mathrm{mm} . \mathrm{Hg})\end{array}$} & \multicolumn{2}{|c|}{$\underset{\text { saturation }}{\text { Per cent } \mathrm{O}_{2}}$} & \multirow{2}{*}{$\begin{array}{c}\text { A-V O } \\
\text { difference } \\
\text { (vols. \%) }\end{array}$} & \multirow{2}{*}{$\begin{array}{l}\text { Cardiac } \\
\text { output }\end{array}$} & \multirow{2}{*}{$\begin{array}{c}\text { Cardiac } \\
\text { index }\end{array}$} & \multirow{2}{*}{$\begin{array}{l}\text { Total } \\
\text { pulmonary } \\
\text { resistance }\end{array}$} & \multirow{2}{*}{$\begin{array}{l}\text { Pulmonary } \\
\text { vascular } \\
\text { resistance }\end{array}$} \\
\hline & & & & P.A. & B.A. & & & & & \\
\hline $\begin{array}{l}\text { Basal } \\
\text { Exercise }\end{array}$ & .. & $\begin{array}{l}. . \\
.\end{array}$ & $\begin{array}{l}72 \\
94\end{array}$ & $\begin{array}{l}60 \\
32\end{array}$ & $\begin{array}{l}90 \\
92\end{array}$ & $\begin{array}{r}6 \cdot 1 \\
11 \cdot 5\end{array}$ & $\begin{array}{l}4.0 \\
3.0\end{array}$ & $\begin{array}{l}2 \cdot 8 \\
2 \cdot 1\end{array}$ & $\begin{array}{l}1310 \\
2450\end{array}$ & 910 \\
\hline
\end{tabular}

\section{Surgical Treatment}

Mitral valvotomy was performed in five patients-in four by Mr. Frank Nicholson and in one (Case 6) by Mr. Gordon Jack. Some operative findings and results are shown in Table IV. Tight mitral stenosis was a constant finding - the valve size being estimated as less than $0.5 \mathrm{~cm}$. in four patients and less than $1 \mathrm{~cm}$. in the other. Moderate and heavy calcification of the mitral valve was present in two patients (Cases 1 and 3).

The surgeon judged that a good "split" of the mitral valve was obtained in four patients, and a moderate one in the fifth (Case 3). One (Case 2) died twelve hours after operation without regaining consciousness: permission for a necropsy was not obtained and the exact cause of death was not ascertained.

Three patients have shown striking subjective and objective improvement as a result of valvotomy. Signs of pulmonary hypertension have disappeared, heart size has diminished, and clinical and radiological pulmonary congestion has improved (Fig. 3). The electrocardiogram has returned to normal in one patient (Fig. 3) and is still improving in two.

Two of these patients, from being completely incapacitated with resistant congestive heart failure requiring low sodium diet and diuretics, have improved to functional grade I and now lead a normal life without any specific treatment. The other patient is now in Grade II. The fourth (Case 6) who was operated on quite recently is already functionally improved and radiologically 

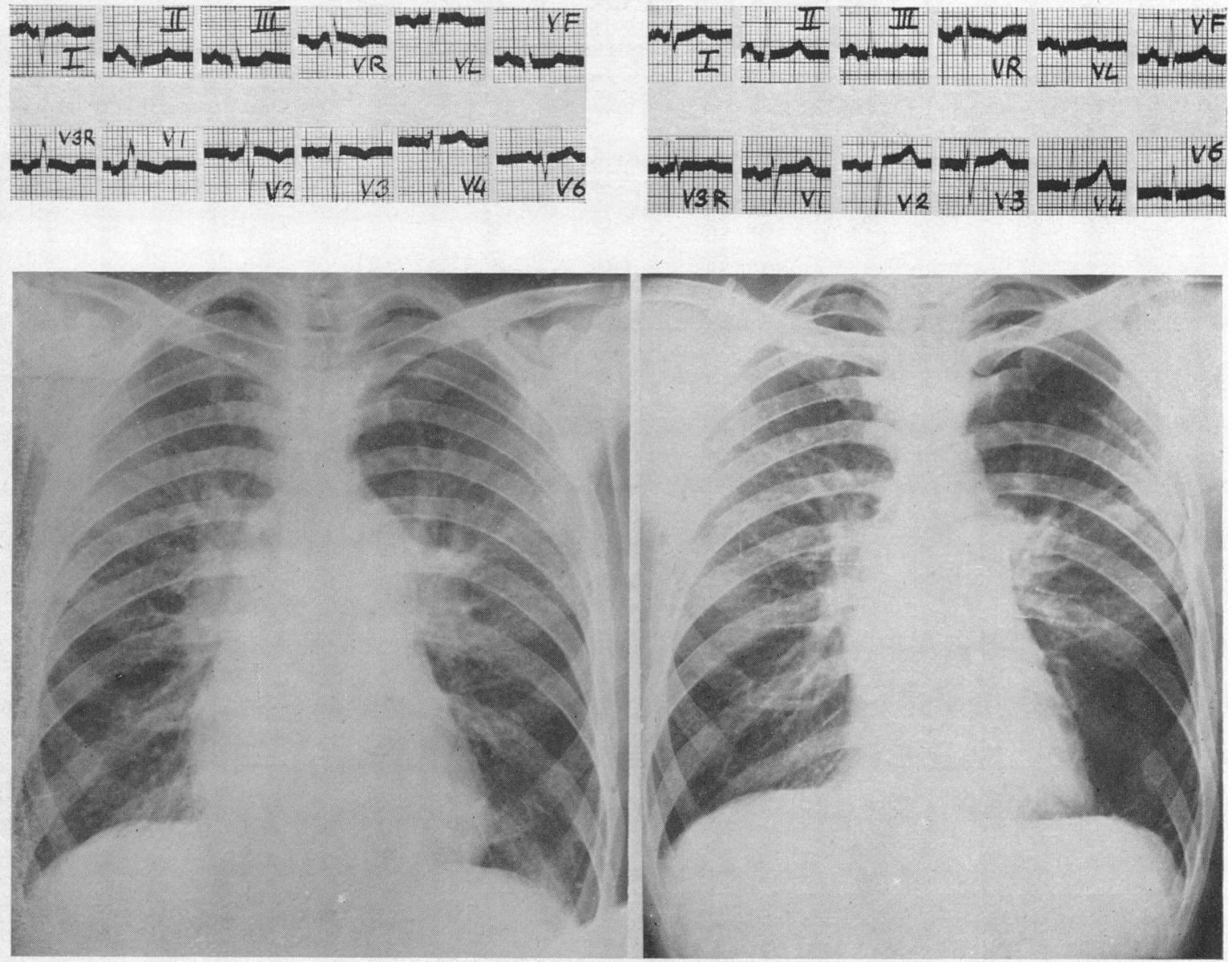

A

B

FIG. 3.-Chest radiographs and electrocardiograph of Case 1. (A) Before mitral valvotomy, and (B) 32 months after, showing reduction in heart size and pulmonary congestion. The cardiogram had returned to normal.

the proximal branches of the pulmonary arteries are less prominent. The post-operative period was smooth in the four surviving patients and the early disappearance of orthopnœa was a noticeable feature in two of them. Auricular fibrillation occurred in one patient but normal rhythm was restored with quinidine sulphate on the twelfth day after operation.

TABLE IV

Findings AT AND Results of Surgery

\begin{tabular}{c|c|c|c|c}
\hline $\begin{array}{c}\text { Case } \\
\text { No. }\end{array}$ & $\begin{array}{c}\text { Valve } \\
\text { calcification }\end{array}$ & \multicolumn{2}{|c|}{$\begin{array}{c}\text { Valve } \\
\text { size } \\
(\mathrm{cm} .)\end{array}$} & $\begin{array}{c}\text { Functional } \\
\text { grade } \\
\text { after } \\
\text { operation }\end{array}$ \\
\cline { 2 - 5 } & Before & After & \\
\hline 1 & Heavy & $>\frac{1}{2}$ & $2 \cdot 5$ & I \\
2 & None & $>\frac{1}{2}$ & 3 & Died \\
3 & Moderate & $>\frac{1}{2}$ & 3 & II \\
4 & None & $>\frac{1}{2}$ & $2 \cdot 5$ & I \\
6 & None & $>1$ & 3 & III \\
\hline
\end{tabular}


Cardiac catheterization was performed in Cases 4 and 6 four weeks after operation and in Case 1 thirty-two months after, and the results are shown in Table V. In Cases 1 and 4 dramatic reduction in pulmonary arterial pressure $(22$ and $40 \mathrm{~mm}$. $\mathrm{Hg}$ ) and P.C.V. pressure (14 and $8 \mathrm{~mm} . \mathrm{Hg})$ was found (Fig. 4). Pulmonary resistance in Case 1 was found to be only slightly increased at postoperative catheterization and although it was not measured before, it must by implication have been high. The pulmonary artery in the third patient (Case 6) was not catheterized and although

TABLE $\mathrm{V}$

Post-operative Cardiac Catheterization

\begin{tabular}{|c|c|c|c|c|c|c|c|c|c|c|c|c|}
\hline \multirow{2}{*}{\multicolumn{2}{|c|}{$\begin{array}{l}\text { Case } \\
\text { No. }\end{array}$}} & \multirow{2}{*}{\multicolumn{3}{|c|}{$\begin{array}{c}\text { P.A. pressure } \\
\text { Systolic Diastolic Mean }\end{array}$}} & \multirow{2}{*}{$\begin{array}{l}\text { Mean } \\
\text { P.C.V. } \\
\text { pressure } \\
(\mathrm{mm} . \mathrm{Hg})\end{array}$} & \multicolumn{2}{|c|}{$\begin{array}{l}\mathrm{Per} \text { cent } \mathrm{O}_{2} \\
\text { saturation }\end{array}$} & \multirow{2}{*}{$\begin{array}{r}\text { A-V O } \mathrm{O}_{2} \\
\text { difference } \\
\text { (vols. \%) }\end{array}$} & \multirow{2}{*}{$\begin{array}{l}\text { Cardiac } \\
\text { output } \\
\text { (1. min.) }\end{array}$} & \multirow{2}{*}{$\begin{array}{c}\text { Cardiac } \\
\text { index }\end{array}$} & \multirow{2}{*}{$\begin{array}{c}\text { T.P.R. } \\
\text { (dynes sec } \mathrm{cm} \text { - }^{-5} \text { ) }\end{array}$} & \multirow{2}{*}{$\begin{array}{c}\text { P.V.R. } \\
\text { (dynes sec cm.-5) }\end{array}$} \\
\hline & & & & & & P.A. & B.A. & & & & & \\
\hline 1 & $\begin{array}{l}\text { Pre-op. } \\
\text { Post-op }\end{array}$ & & & $\begin{array}{l}74 \\
22\end{array}$ & $\begin{array}{l}35 \\
14\end{array}$ & $\begin{array}{l}46 \\
71\end{array}$ & $\begin{array}{l}96 \\
96 \cdot 2\end{array}$ & $\begin{array}{r}10 \cdot 4 \\
5 \cdot 1\end{array}$ & $4 \cdot 7$ & 2.8 & 292 & 146 \\
\hline 4 & $\begin{array}{l}\text { Pre-op. } \\
\text { Post-op }\end{array}$ & $\begin{array}{r}125 \\
66\end{array}$ & $\begin{array}{l}44 \\
24\end{array}$ & $\begin{array}{l}72 \\
40\end{array}$ & $\begin{array}{r}25 \\
8\end{array}$ & 60 & $\frac{90}{-}$ & $6 \cdot 1$ & $4 \cdot 0$ & $2 \cdot 8$ & 1310 & 910 \\
\hline 6 & $\begin{array}{l}\text { Pre-op. } \\
\text { Post-op }\end{array}$ & $\begin{array}{r}177 \\
\text { R.V. } \\
140\end{array}$ & 91 & 123 & - & $\begin{array}{c}53 \\
\text { R.V. } \\
63 \cdot 5\end{array}$ & $94 \cdot 6$ & $\begin{array}{l}8 \cdot 0 \\
5 \cdot 1\end{array}$ & $3 \cdot 2$ & $2 \cdot 1$ & 2930 & - \\
\hline
\end{tabular}

R.V.= Right ventricle.

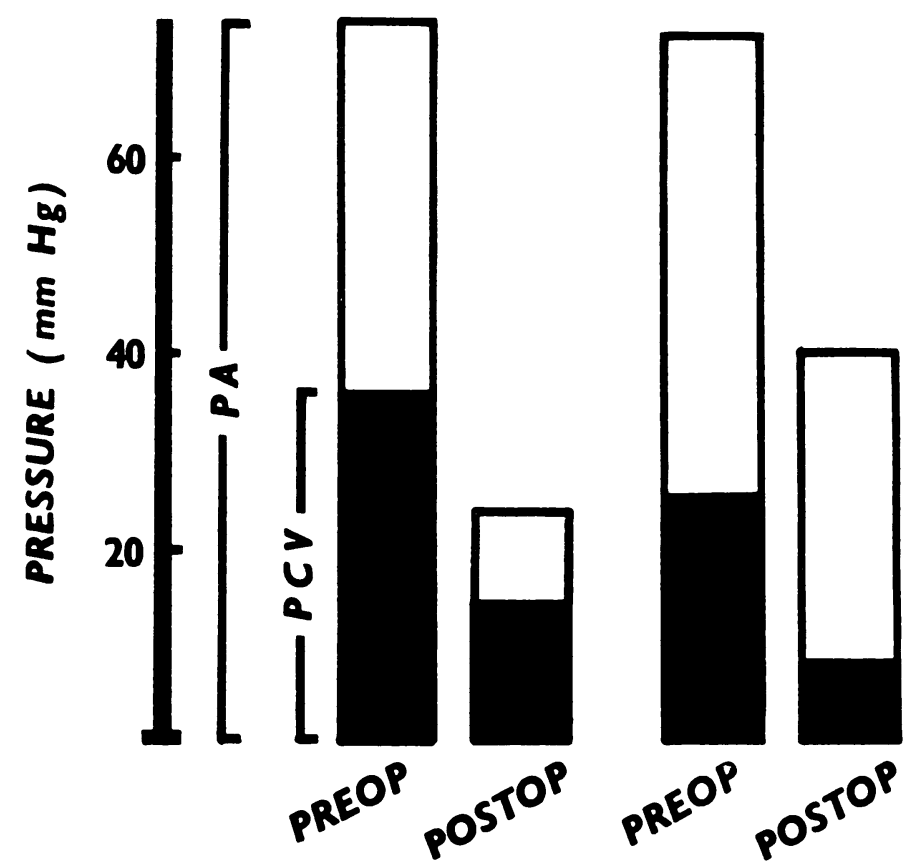

FIG. 4.-Histogram, showing fall in mean pulmonary artery and pulmonary capillary venous pressure after mitral valvotomy in two patients (Cases 1 and 4 ).

right ventricular systolic pressure showed a fall to $140 \mathrm{~mm}$. $\mathrm{Hg}$, severe pulmonary hypertension persisted. The oxygen saturation of right ventricular blood had, however, increased and the arterio-venous oxygen difference had fallen, suggesting that cardiac output was probably higher and pulmonary resistance lower than previously. 


\section{Discussion}

Mitral stenosis usually runs a long course with an average duration from onset of symptoms to total incapacity of from seven (Wood, 1954) to fifteen years (Olesen, 1955); the symptoms are mainly ascribable to congestion of the pulmonary capillary bed, namely breathlessness on exertion, paroxysmal dyspnœa, hæmoptysis, and orthopnœa. By contrast our six patients deteriorated rapidly after the onset of symptoms and all reached total incapacity within seven years, the duration of symptoms being three years or less in four of them. Their symptoms consisted of fatigue and exhaustion as well as breathlessness on exertion, and exertional syncope occurred in two patients. Despite the invariable tight mitral stenosis, orthopnœa, paroxysmal cardiac dyspnœa, and hæmoptysis may be absent. None of our patients described anginal pain on exertion though for many years this symptom has been known to occur in patients with mitral stenosis complicated by pulmonary atherosclerosis: Stuckey (1955) suggested that it occurs as a result of inadequate coronary blood flow during exercise due to a fixed, low cardiac output. Low cardiac output was found in all three cases in which it was estimated; further, it may remain fixed or fall on exertion and this is associated with increased pulmonary vascular resistance (Case 4; Donald et al, 1954). A striking feature is the early onset of congestive heart failure and its resistance to intensive treatment.

The physical signs in this group are quite different from those found in most patients with mitral stenosis. In addition to obvious signs of pulmonary hypertension our patients had a striking appearance with malar cyanotic flush, cold cyanosed extremities, small pulse, and low arterial blood pressure. The characteristic murmurs of mitral stenosis were much modified and the diastolic murmur may be extremely soft or entirely absent. There may be no murmurs or only an apical systolic or tricuspid systolic murmur indicative of tricuspid incompetence. Some degree of pulmonary incompetence is not uncommon. The reduced intensity or absence of the usual diastolic and presystolic murmurs of mitral stenosis is presumably due to the small volume of blood flowing through the tightly stenosed mitral valve, though it is possible that mitral calcification may have been a factor in the modification of the auscultatory signs in three of our patients (Mounsey, 1953). The electrocardiograph invariably shows the characteristic changes of right ventricular enlargement and either a P pulmonale or P mitrale may be present (Wood, 1954).

The diagnosis can usually be confirmed by finding the radiological changes of mitral stenosis and pulmonary hypertension (Wade et al., 1952) with little peripheral pulmonary congestion (Fig. 2). The demonstration of a raised P.C.V. pressure at cardiac catheterization provides confirmatory evidence, but we have experienced difficulty in wedging the catheter tip in these patients, presumably owing to pulmonary arterial narrowing. The striking finding is the great increase in pulmonary vascular resistance which arises in the small muscular arteries (Davies et al., 1953). This may either be the result of organic narrowing (Parker and Weiss, 1936; Larrabee et al., 1949) or secondary to reversible vasoconstriction, the mode of production of which remains unknown. The increased hindrance in the region of the terminal muscular arteries undoubtedly protects the capillary bed from the output of the right ventricle, lessening the severity of symptoms due to capillary congestion. This is clearly shown in Fig. 5 which is a biopsy section from the lower lobe of the left lung of Case 6 taken during mitral valvotomy; the capillaries show surprisingly little congestion despite the tight mitral stenosis (less than $1 \mathrm{~cm}$.). Wood (1952) has put forward a teleological concept of protective vasospasm but the inconstancy of this type of response renders it unlikely that this is a protective reflex mechanism. Moreover, it is of very doubtful value, for death occurs in these cases with unusual rapidity due to congestive heart failure.

Three of five patients have responded well to mitral valvotomy, two being restored to a normal life: it is still too early to assess the result in the fourth survivor. Thirty-two months after operation in Case 1, pulmonary dynamics are normal and in Case 4 the mean pulmonary artery pressure had fallen by about 50 per cent in four weeks. The remarkable clinical, radiological, and cardiographic improvement in Case 3 also must imply a considerable fall in pulmonary artery pressure. It seems probable that both vasospasm and structural changes are concerned in the maintenance of the 


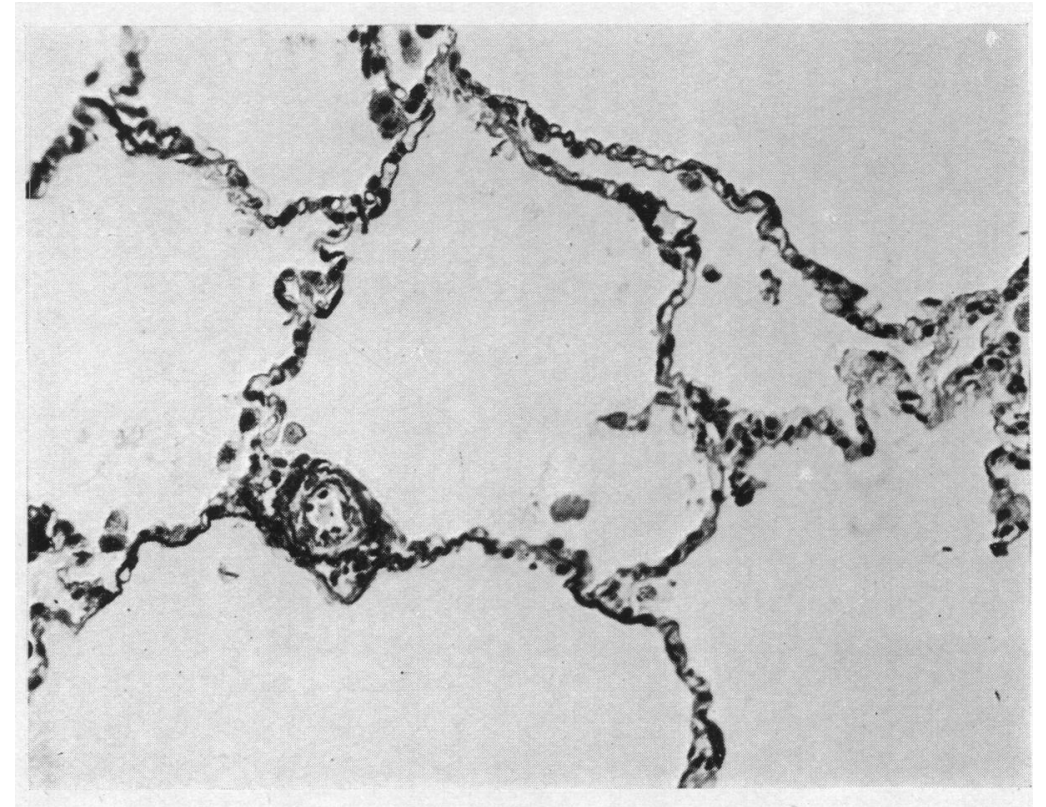

Fig. 5.-Section from lower lobe of left lung (Case 6) removed at operation, showing only slight capillary congestion in spite of severe mitral stenosis.

increased pulmonary resistance but, and this is the important fact, whatever the mechanism may be, it is potentially reversible. It is especially important, therefore, that the syndrome should be recognized for it is an urgent indication for surgery.

\section{SUMMARY}

The clinical and other features of six patients with mitral stenosis and very high pulmonary vascular resistance are reported. All had tight mitral stenosis with a valve less than $1 \mathrm{~cm}$. in diameter. The natural history is short with early and intractable congestive heart failure. The symptoms are mainly those of limited cardiac output and those due to pulmonary capillary congestion may or may not be present. The physical signs of pulmonary hypertension dominate the clinical picture and the characteristic murmurs of mitral stenosis may be greatly modified or absent.

Five patients were submitted to mitral valvotomy with excellent results in three and one death; it is still too soon to assess the result in the fifth. The excellence of the operative results stresses the need for early recognition.

We are grateful to Dr. A. Morgan Jones for advice and encouragement and for permission to study patients under his care, and to Dr. J. L. Taylor and Mr. Gordon Jack for allowing us to investigate Case 6. Our thanks are due to Mr. R. C. de Meneaud for technical assistance.

\section{REFERENCES}

Davies, L. G., Goodwin, J. F., Steiner, R. E., and Van Leuven, B. D. (1953). Brit. Heart J., $15,393$.

Donald, K. W., Bishop, J. M., and Wade, O. L. (1954). J. Clin. Invest., 33, 1146.

Eliasch, H., Wade, G., and Werkö, L. (1952). Circulation, 5, 271.

Kerley, P. (1951). Textbook of X-ray Diagnosis. London.

Larrabee, W. F., Parker, R. L., and Edwards, J. E. (1949). Proc. Mayo Clin., 24, 316.

Mounsey, P. (1953). Brit. Heart J., 15, 135.

Olesen, K. H. (1955). Mitral Stenosis, A Follow-up of 351 Patients. Munksgaards, Copenhagen.

Parker, F., and Weiss, S. (1936). Amer. J. Path., 12, 573.

Stuckey, D. (1955). Brit. Heart J., 17, 397.

Wade, G., Werkö, L., Eliasch, H., Gidlund, A., and Lagerlöf, H. (1952). Quart. J. Med., $21,361$.

Wood, P. (1952). Brit. med. Bull., 8, 348.

(1954). Brit. med. J., 1, 1051 . 